\title{
Assessment of coronary atherosclerosis by IVUS and IVUS-based imaging modalities: progression and regression studies, tissue composition and beyond
}

\author{
Bill D. Gogas • Vasim Farooq • \\ Patrick W. Serruys $\cdot$ Hector M. Garcìa-Garcìa
}

Received: 7 December 2010/Accepted: 30 December 2010/Published online: 4 March 2011

(C) The Author(s) 2011. This article is published with open access at Springerlink.com

\begin{abstract}
Cardiovascular disease remains the leading cause of mortality, morbidity and disability in the developed world, predominantly affecting the adult population. In the early 1990s coronary heart disease (CHD) was established as affecting one in two men and one in three women by the age of forty. Despite the dramatic progress in the field of cardiovascular medicine in terms of diagnosis and treatment of heart disease, modest improvements have only been achieved when the reduction of cardiovascular mortality and morbidity indices are assessed. To better understand coronary atherosclerosis, new imaging modalities have been introduced. These novel imaging modalities have been used in two ways: (1) for the characterization of plaque types; (2) for the assessment of the progression and regression of tissue types. These two aspects will be discussed in this review.
\end{abstract}

Keywords Intravascular ultrasound .

Tissue characterization $\cdot$ Atherosclerosis

B. D. Gogas · V. Farooq · P. W. Serruys ·

H. M. Garcìa-Garcìa $(\square)$

Department of Interventional Cardiology,

Thoraxcenter, Erasmus University Medical Center,

z120 Erasmus MC Dr Molerwaterplein 40,

3015 GD Rotterdam,

The Netherlands

e-mail: h.garciagarcia@erasmusmc.nl

\section{Introduction}

Atherogenesis is a chronic and evolving inflammatory process. Many theories have been proposed to explain the initiation and progression of the atheromatous plaque from the asymptomatic "raised fatty streak or intimal xanthoma" and proatheroma (types II and III lesions respectively_AHA classification) to the formation of the symptomatic and obstructive complicated fibroatheroma (type VI lesion_AHA classification). During the formation of these plaques, a critical primary step is the accumulation and oxidation of low-density lipoprotein (LDL) particles. Oxidized-LDL favours leukocyte recruitment and activation as well as cell death, which leads to the generation of complex atherosclerotic plaques [2]. These high-risk atherosclerotic plaques have a particular phenotype that is characterized by a high content of necrotic core, a thin inflamed fibrous cap (due to intense accumulation of macrophages) and the scarce presence of smooth muscle cells. Within the necrotic core, underlying the thin fibrous cap, hemorrhage, calcification and intraplaque vasa vasorum are frequently found $[3,4]$.

IVUS and IVUS-based imaging modalities have the potential to be able to provide useful insights into the different phases of the development of the plaque, as well as the different key players in this process (i.e. components of the plaque such as necrotic core). In this review, we will discuss the capabilities and limitations of IVUS-based tissue 
characterization imaging modalities in providing this information.

\section{Plaque type characterization}

Detection of calcification

On IVUS, calcium appears as bright echoes with acoustic shadowing. Dense calcium obstructs the penetration of ultrasound Fig. 1. As a consequence, IVUS detects only the leading edge of calcium and therefore cannot determine its thickness. Calcification on IVUS is usually described by its circumferential angle (arc), longitudinal length and depth. Calcification can be located deeper in the arterial wall or at the surface of the plaque, in close contact with the lumen wall interface, and can produce reverberations or repeated reflections at reproducible distances. IVUS has shown a significantly higher sensitivity than fluoroscopy in the detection of coronary calcification. [5] As compared to histology, virtual histology has a predictive accuracy of $96.7 \%$ in the detection of dense calcium [6] (Fig. 1).
Arterial remodeling and plaque composition

Arterial remodeling refers to a continuous process involving changes in vessel size as measured by the EEM cross-sectional area; this is also known as the vessel cross-sectional area-CSA. "Positive remodeling" occurs when there is an outward increase in EEM and "negative remodeling" occurs when the EEM decreases in size (i.e. shrinkage of the vessel) [7]. The magnitude and direction of remodeling can be expressed by following index: EEM cross-sectional area at the plaque site divided by EEM CSA at the reference "non-diseased" vessel site. Positive remodeling demonstrates an index $>1.05$ whilst negative remodelling has an index $<0.95$. Direct evidence of remodeling can only be demonstrated in serial studies showing changes in the EEM CSA over time, since remodeling may also occur at the "normal-appearing" reference coronary segment [7]. The limitations of coronary angiography in determining disease burden and stenosis severity are largely due to the effects of vessel remodeling. Pathological studies have also suggested a potential relationship between positive vessel remodeling and plaque vulnerability. Vessels

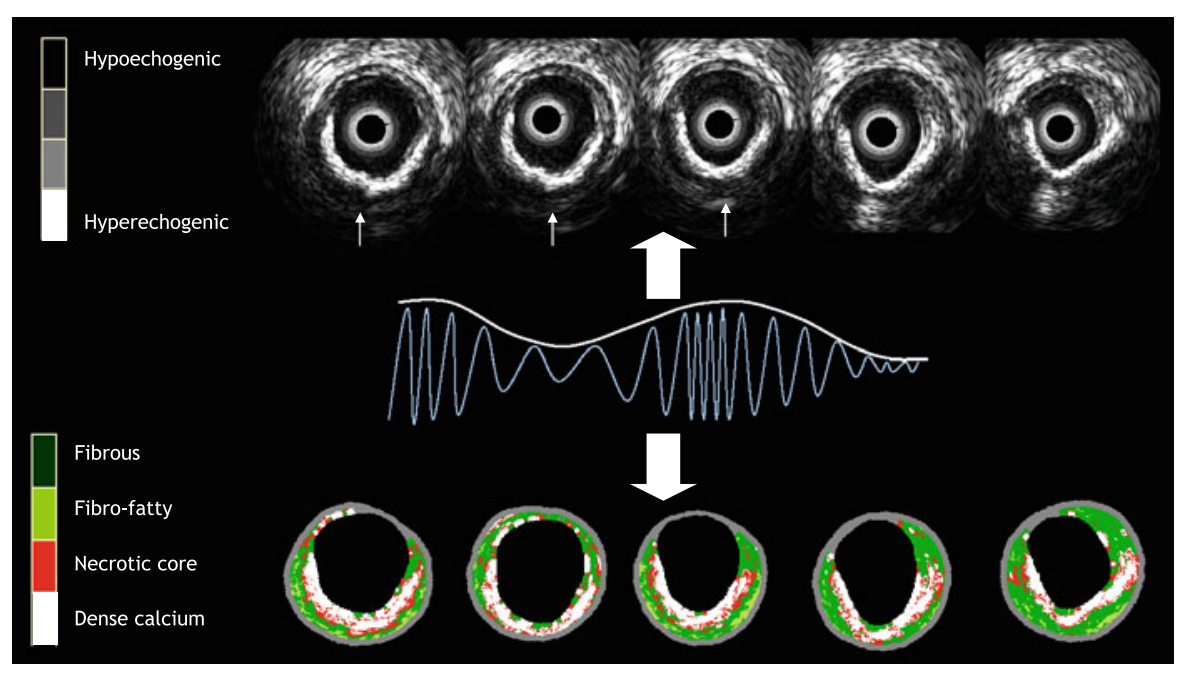

Fig. 1 Cross sections of IVUS and corresponding VH-IVUS frames characterizing a calcified plaque. Grey scale IVUS has both a high sensitivity and specificity in the detection of calcium. Calcium usually obstructs the penetration of ultrasound and consequently obscures the imaging of the underlying vascular wall; this phenomenon is known as acoustic shadowing (thin white arrows in the top panel). The corresponding IVUS virtual histology frames are shown at the bottom of the figure with the dense calcium being shown in white. The greyscale image is reconstructed from the amplitude of the signal whereas with virtual histology, the underlying radiofrequency data is used for tissue characterization as illustrated 
with positive remodeling have shown an increase in inflammatory marker concentrations, larger lipid cores, paucity of smooth muscle cells and medial thinning [8-10]. Several IVUS studies have linked positive vessel remodelling with culprit [11] and ruptured coronary plaques $[12,13]$. Positive remodelling has also been observed more often in patients with acute coronary syndromes than in those with stable coronary artery disease $[14,15]$, and has been identified as an independent predictor of major adverse cardiac events in patients with unstable angina [16]. Plaques exhibiting positive remodelling also more often have evidence of thrombus and signs of rupture [17]. The patterns of remodelling have also been correlated with plaque composition; soft plaques are associated with positive remodelling whilst fibrocalcific plaques are more often associated with negative or constrictive remodelling [18]. Similar findings have been observed in studies utilizing IVUS virtual histology analyses, a technique developed specifically for tissue characterization; positive remodelling was found to directly correlate with the presence and size of necrotic core, and was inversely associated with the presence of fibrotic tissue [19].

Vulnerable plaque and thrombi

Acute coronary syndromes are often the first manifestation of coronary atherosclerosis, making the identification of plaques at high-risk of complications an important component of strategies to reduce casualties associated with atherosclerosis. Our current understanding of plaque biology suggests that $\sim 60 \%$ of clinically evident plaque rupture originates within an inflamed thin-capped fibroatheroma [20, 21]. Pathological studies have demonstrated that ruptured plaques are mainly located in the proximal portions of the LAD and LCX and are more disperse within the RCA [22]. This tendency of advanced plaques to preferentially develop in these locations has been explained by the low shear stress conditions generated in areas with tortuosity or many branches. Low shear stress may induce the migration of lipid and monocytes into the vessel wall, which may lead to further progression of the lesion towards a plaque with high risk of rupture [23].

The definition of an IVUS-derived TCFA is a lesion fulfilling the following criteria in at least 3 frames: (1) plaque burden $\geq 40 \%$; (2) confluent necrotic core $\geq 10 \%$ in direct contact with the lumen (i.e. no visible overlying tissue) [24]. By using this definition of IVUS-derived TCFA, in patients with ACS who underwent IVUS of all three epicardial coronaries, on average 2 IVUS-derived thin cap fibroatheromas were found per patient with half of these patients showing evidence of outward remodelling. [24].

Hong et al. [25] reported the frequency and distribution of TCFA identified by virtual histology intravascular ultrasound in acute coronary syndrome $(\mathrm{ACS}=105 \mathrm{pts})$ and stable angina pectoris $(\mathrm{SAP}=107 \mathrm{pts})$ in a 3 -vessel IVUS-VH study. The findings showed that there were $2.5 \pm 1.5$ TCFAs per patient with ACS and 1.7 \pm 1.1 TCFAs per patient with SAP, $P<0.001$. The presentation of ACS was the only independent predictor for multiple ID-TCFA $(P=0.011) .83 \%$ of ID-TCFAs were located within $40 \mathrm{~mm}$ of the proximal coronary artery.

The potential value of these VH IVUS-derived plaque types to predict adverse coronary events was evaluated in an international multicentre prospective study, the Providing Regional Observations to Study Predictors of Events in the Coronary Tree study (PROSPECT study) [26].

The PROSPECT trial was a multi-center, natural history study of acute coronary syndrome patients. All patients underwent PCI to their culprit lesion at baseline, followed by an angiogram and IVUS virtual histology of all three major coronary arteries. One of the main findings was that a TCFA, with a minimum lumen area of $\leq 4 \mathrm{~mm}^{2}$, and a large plaque burden $(\geq 70 \%$ ), had a $17.2 \%$ likelihood of causing a future event within three years [26]. Interestingly, the anticipated higher frequency of acute thrombotic cardiovascular events did not occur, with only a $1 \%$ rate of myocardial infarction and no deaths directly attributable to non-culprit vessels over a period of 3 years follow-up. These results suggest that nonculprit obstructive coronary plaques were more likely to be associated with increasing anginal symptoms rather than thrombotic acute events, with $8.5 \%$ of patients presenting with worsening angina and $3.3 \%$ with unstable angina.

Plaque ruptures occur at sites of significant plaque accumulation, but are often not highly stenotic, as defined by coronary angiography due to positive vascular remodeling $[12,13,27]$. The transition to 
plaque rupture has been characterized by the presence of active inflammation (monocyte and macrophage infiltration), thinning of the fibrous cap $(<65 \mu \mathrm{m})$, development of a large lipid necrotic core, endothelial denudation with superficial platelet aggregation and intraplaque hemorrhage [28]. The remaining plaques that can cause ACS contain calcium nodules $(\sim 10 \%)$ or have none of the pathological features described above $(\sim 20 \%)$. Superficial plaque erosion can explain at least a portion of the latter events, particularly in women and diabetics [29]. The lack of a cellular or anatomical signature of plaque erosion can make it difficult for existing imaging methods to have a high accuracy in predicting future ACS events. In addition, most plaque ruptures are frequently clinically silent; the occurrence of repetitive healed plaque ruptures may contribute to the progression of stable coronary disease into obstructive disease [30].

Ruptured plaques may have a variable appearance on IVUS. Most commonly, IVUS may reveal an "axial", abrupt ulceration depicted as an echolucent "void" or cavity beginning at the luminal-intimal border. These features should be distinguished from a longitudinal tear of the intima and media associated with spontaneous or iatrogenic dissection. The tear of the rupture in the fibrous cap can be identified in approximately $60 \%$ of the cases and occurs more often at the shoulder of the plaque than in the centre $[12,31,32]$. Due to its relatively poor resolution, IVUS is unsuitable to detect a thin fibrous cap. However, IVUS often reveals other features of ruptured plaques which are large in volume, eccentric, have mixed or soft composition and irregular surface, and are associated with expansive remodelling [12, 13, 33, 34]. Ruptured plaques have been shown to have quantitatively less calcium, especially superficial calcium, but a larger number of small $\left(<90^{\circ}\right.$ arc $)$ calcium deposits, particularly deep calcium deposits [35]. IVUS can also reveal blood speckles passing through intra-plaque channels created by the rupture. These usually produce a typical hazy, complex with non stenotic angiographic appearances of the ruptured plaques.

Several IVUS studies have reported the frequency and distribution of plaque ruptures during investigation of the three coronary epicardial vessels. Rioufol et al. studied 24 patients ( 72 arteries) with ACS and found a mean prevalence of two ruptured plaques per patient. Interestingly, $12.5 \%$ of these patients had ruptured plaques in the three major coronary arteries. Only $37.5 \%$ of the ruptured plaques were located at the culprit lesion, and $79 \%$ of the patients also had a ruptured plaque located somewhere other than at the culprit lesion [36]. In a similar study in 45 patients with acute myocardial infarction (AMI), plaque rupture was observed in 21 patients $(47 \%)$ at the culprit site and 17 additional plaque ruptures were found at remote sites in 11 patients (24\%) [37]. Hong et al., evaluated the incidence of plaque rupture depending on the clinical presentation. They performed 3-vessel IVUS examination in 235 patients (122 AMI and 113 stable angina pectoris-SAP). Plaque rupture of infarct-related or target lesions occurred in $66 \%$ of AMI patients and in $27 \%$ of SAP patients. Non-infarct-related or non-target artery plaque ruptures occurred in $17 \%$ of AMI patients and $5 \%$ of SAP patients. Multiple plaque ruptures were observed in $20 \%$ of AMI and $6 \%$ of SAP patients [38]. The same authors evaluated the distribution of plaque rupture in native coronary arteries in 392 patients (231 ACS and 161 SAP). Three-vessel IVUS imaging showed that plaque ruptures occurred mainly in the proximal segments of the LAD (83\% of LAD ruptured plaques), the proximal and distal segments of the RCA (48 and $32 \%$ of RCA ruptured plaques, respectively), and the entire LCX [39]. These results are in line with another study that included 104 patients and studied 160 ruptured plaques in the $\mathrm{LAD}$, the majority of plaque ruptures were located within the proximal $30 \mathrm{~mm}$ of the artery [40].

A study aimed at characterizing plaque ruptures in the left main coronary artery (LMCA) found 16 plaque ruptures in 17 patients (2 AMI, 13 unstable angina and $1 \mathrm{SAP}$ ). The ruptures were located in the distal portion and/or bifurcation of the LMCA, often did not compromise the lumen, and had an angiographic complex appearance. When ruptured plaques involved the bifurcation LAD-LCX, they often occurred opposite to the flow divider [41]. This is in line with findings made by our group; lesions involving the bifurcation LAD-LCX were predominantly located in the outer wall of the carina, and such locations were often associated with a larger necrotic core content [42].

Ruptured atherosclerotic plaques in native coronary arteries are well described with intravascular ultrasound; they are however, not well described in 
saphenous vein grafts (SVGs). In 791 pre-intervention IVUS SVG studies, 95 ruptured plaques in 76 SVGs (73 patients) were identified (prevalence of 9.7\%). These ruptured plaques were found to be associated with complex angiographic characteristics and expansive remodelling [43, 44]. Likewise, in an analysis of 300 ruptured plaques in SVGs in 254 patients, Maehara et al., demonstrated that ruptured plaques, as detected by IVUS, strongly correlated with a complex angiographic lesion morphology: ulceration in $81 \%$, intimal flap in $40 \%$, thrombus in $7 \%$, and aneurysm in $7 \%$ [12].

IVUS has also been used to assess the natural evolution of ruptured plaques. IVUS studies have suggested that up to $50 \%$ of the ruptured plaques detected in a first ACS event heals with medical therapy, without a significant change in plaque size [45]. One study revealed complete healing of plaque rupture in $29 \%$ of patients treated with statins and incomplete healing in untreated patients [46].

The ruptured plaque profile in 40 patients referred for cardiac catheterization has previously been described [47]. In total, there were 13 patients with stable angina, 12 with unstable angina, and 15 with acute myocardial infarction. Ruptured plaque was identified in 26 patients and, as expected, was more frequent in patients with acute myocardial infarction and unstable angina. Patients with ruptured plaques were found to have a larger body mass index, were more likely to be smokers and had more diffuse calcification and necrotic core areas when compared to those patients without plaque rupture. Of note, is that the location of plaque ruptures in this study mirrored the pathological findings [48]. In a study performed by our group, the proximal left anterior descending coronary artery was the most common site of plaque rupture. In a pathological series of 79 ruptures, Burke et al. [48] found $74 \%$ of the plaque ruptures occurred in the proximal left anterior descending artery.

Similarly, in a report by Hong et al., the frequency and distribution of ruptured plaques identified by IVUS-VH in acute coronary syndrome (ACS $=105$ pts) and stable angina pectoris $(\mathrm{SAP}=107 \mathrm{pts})$ in a 3-vessel IVUS-VH study were reported. [25] 76 ruptured plaques (55 in ACS and 21 in SAP) were described with the presentation of ACS being the only independent predictor for multiple plaque ruptures $(P=0.013)$.

Although plaque characteristics do not yet influence current therapeutic guidelines, the available clinical imaging modalities, IVUS and IVUS-based tissue characterization techniques such as virtual histology, integrated basckscattered IVUS and iMap, have the ability to identify some of the pathological atheroma features described above (Fig. 2).

Thrombus represents the ultimate pathological feature leading to ACS. Thrombus is usually recognized as

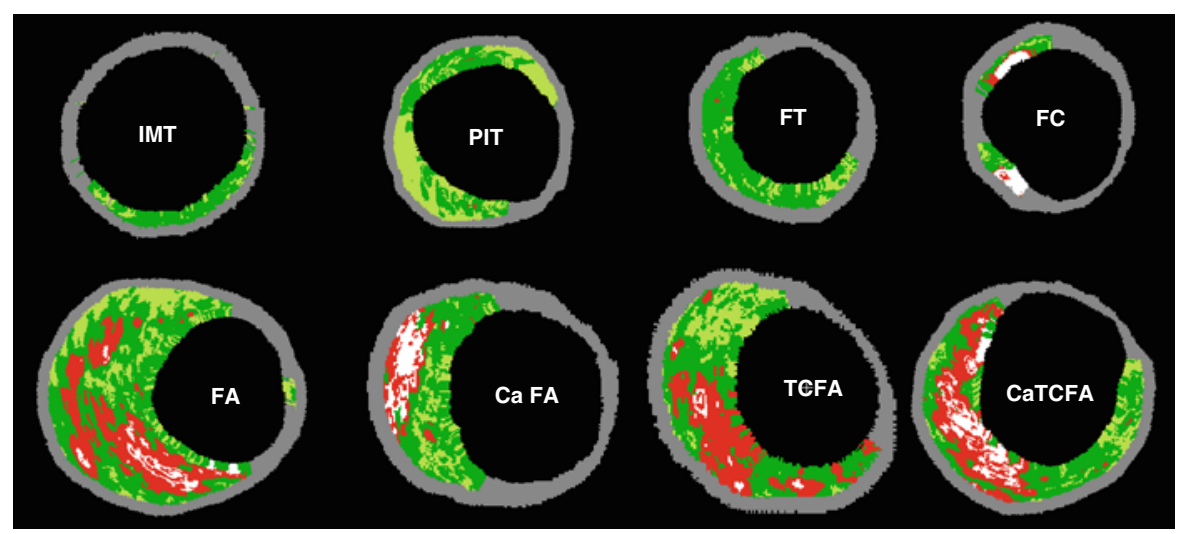

Fig. 2 Examples of VH-IVUS images classified by a twodimensional lesion analysis. (IMT) intimal medial thickening; (PIT) pathological intimal thickening; (FT) fibrotic plaque; (FC) fibrocalcific plaque; (FA) fibroatheroma and (caFA) calcified fibroatheroma; (VH-TCFA) Virtual Histology-thin cap fibroatheroma and (VH-caTCFA) Virtual Histology- calcified thin cap fibroatheroma. Reprinted from EuroIntervention Vol 5, number 2, Garcia-GArcia HM et al. Tissue characterisation using intravascular radiofrequency data analysis: recommendations for acquisition, analysis, interpretation and reporting. Pages 186. Copyright (2009), with permission from Europa Edition 
an echolucent intraluminal mass, often with a layered or pedunculated appearance by IVUS [7]. Fresh or acute thrombus may appear as an echodense intraluminal tissue, which does not follow the circular appearance of the vessel wall, whilst older, more organized thrombus has a darker ultrasound appearance. However, none of these IVUS features are a hallmark for thrombus, and one should consider slow flow (fresh thrombus), air, stagnant contrast or black hole, an echolucent neointimal tissue observed after DES and radiation therapy, as differential diagnoses [7].

None of the IVUS-based imaging modalities available can reliably identify thrombus.

\section{Assessment of progression/regression of coronary atherosclerosis}

Quantification of atheroma or plaque area in crosssectional IVUS images is performed by subtracting the lumen area from the EEL area. Hence, IVUS defined atheroma area is a combination of plaque plus media area. The atheroma area can be calculated in each frame (cross-sectional image), and total atheroma volume (TAV) can be calculated based on pullback speed during imaging acquisition. Atheroma volume can be reported as the percent of the volume of the external elastic membrane occupied by atheroma namely percent atheroma volume (PAV). Parameters commonly used to report the extent of the coronary atherosclerosis are shown in (Fig. 3).

Measurements are performed between the inner lumen border and the media, delineated by the IEL, which corresponds to the "true" histological area of

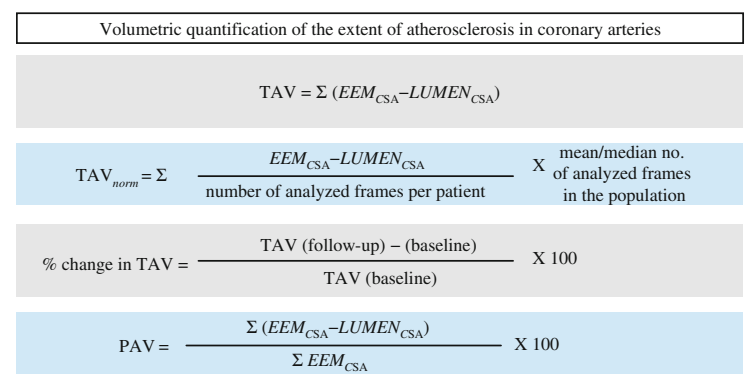

Fig. 3 Parameters commonly used to report the extent of the coronary atherosclerosis are total atheroma volume (TAV) and percent atheroma volume (PAV). EEM, external elastic membrane; CSA, cross-sectional area the atheroma. Intravascular imaging has played an important role in the understanding of atherosclerosis disease in humans and translation of novel therapies to the clinical arena.

\section{Drug effects on atherosclerosis}

The initial observations about a expansive continuous relationship between coronary heart disease risk and blood cholesterol levels led to the conduction of a number of IVUS-based studies to evaluate the effectiveness of differing lipid lowering drugs on atheroma size. Changes in plaque characteristics may be a more relevant endpoint to predict the risk of vascular thrombosis than plaque progression or regression of mild to moderate disease. Imaging tools to accurately evaluate plaque characteristics were not available until recently. Other limitations of using conventional grayscale IVUS to assess the natural history of atherosclerosis should be enumerated: (1) Catheterization, which is an invasive procedure, is required for serial imaging; (2) only a segment of the coronary tree can be studied; (3) plaque composition is not obtained; (4) there is no direct evidence linking changes in coronary plaques and clinical events.

The efficacy of lowering LDL-C with inhibitors of hydroxymethylglutaryl coenzyme A reductase (statins) is unequivocal; however the change in atheroma size by statins is not constant across all IVUS studies. There are many potential explanations for these discrepancies in IVUS studies, such as drug properties, dose, and duration of treatment. Other medications have been studied with IVUS greyscale and IVUS derived imaging modalities (Table 1).

Nevertheless, no single report has been described showing a clear and direct association between reduction in plaque size, composition and/or plaque type with the reduction in clinical events. This is in part due to the fact that clinical outcome studies are expensive, since they have to include a large population (that should be imaged in at least at 2 different time points) that have to be followed up for a prolonged period of time in order to ensure the required number of events have occurred (which are becoming scarce due to the improvements in standards of care) in order to best assess the treatment effect. 


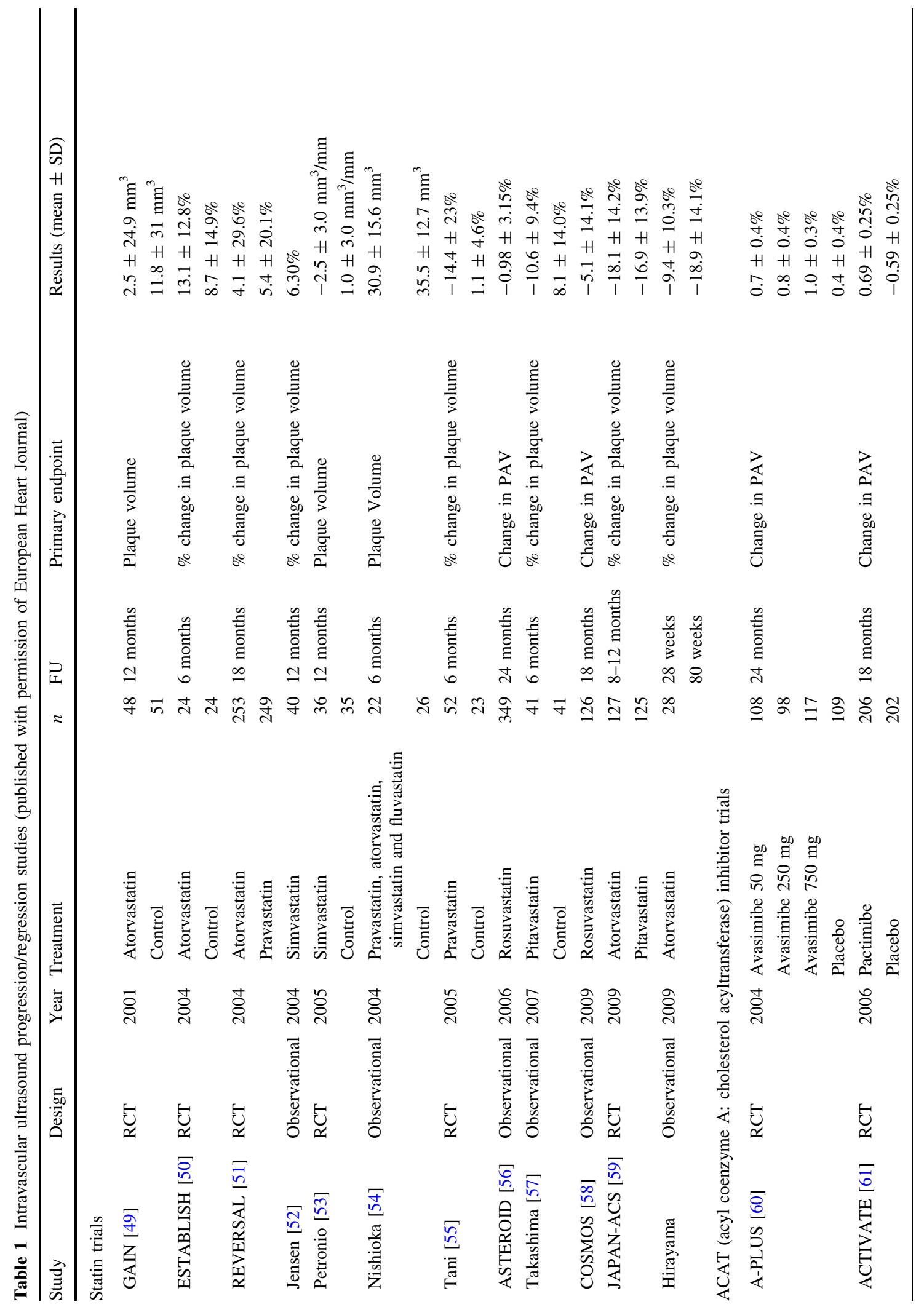




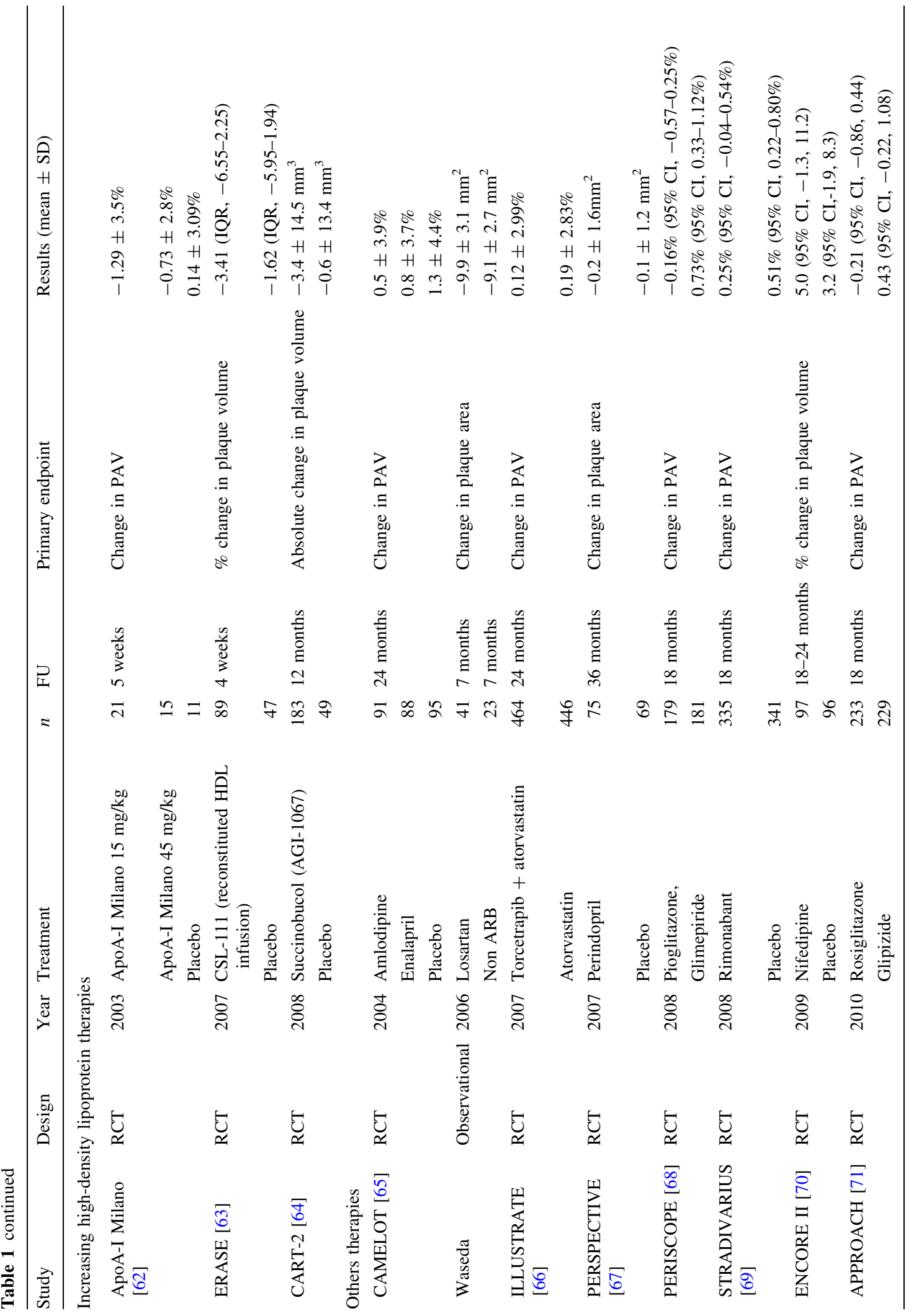




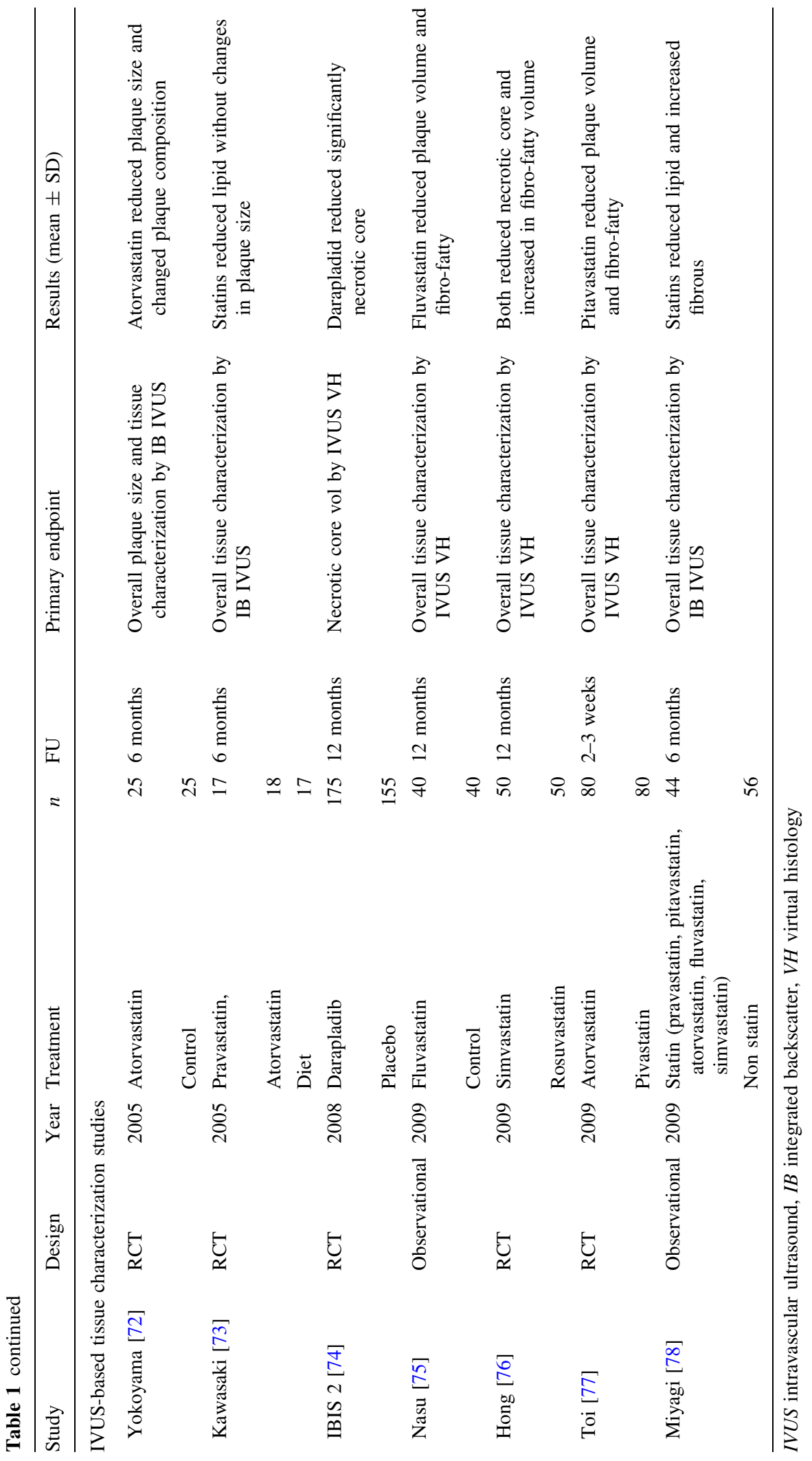


Acknowledgments Bill D. Gogas has received grant support from the Hellenic Heart Foundation.

Open Access This article is distributed under the terms of the Creative Commons Attribution Noncommercial License which permits any noncommercial use, distribution, and reproduction in any medium, provided the original author(s) and source are credited.

\section{Conflict of interest None.}

\section{References}

1. Lloyd-Jones DM, Larson MG, Beiser A, Levy D (1999) Lifetime risk of developing coronary heart disease. Lancet 353(9147):89-92

2. Virmani R, Kolodgie FD, Burke AP, Farb A, Schwartz SM (2000) Lessons from sudden coronary death: a comprehensive morphological classification scheme for atherosclerotic lesions. Arterioscler Thromb Vasc Biol 20(5):1262-1275

3. Burke AP, Farb A, Malcom GT, Liang Y, Smialek JE, Virmani R (1999) Plaque rupture and sudden death related to exertion in men with coronary artery disease. JAMA 281(10):921-926

4. Burke AP, Farb A, Malcom GT, Liang YH, Smialek J, Virmani R (1997) Coronary risk factors and plaque morphology in men with coronary disease who died suddenly. N Engl J Med 336(18):1276-1282

5. Mintz GS, Popma JJ, Pichard AD, Kent KM, Satler LF, Chuang YC, Ditrano CJ, Leon MB (1995) Patterns of calcification in coronary artery disease. A statistical analysis of intravascular ultrasound and coronary angiography in 1,155 lesions. Circulation 91(7):1959-1965

6. MP Nair A, Kuban BD, Vince DG (2007) Automated coronary plaque characterization with intravascular ultrasound backscatter: ex vivo validation. Eurointervention 3:113-130

7. Mintz GS, Nissen SE, Anderson WD, Bailey SR, Erbel R, Fitzgerald PJ, Pinto FJ, Rosenfield K, Siegel RJ, Tuzcu EM, Yock PG (2001) American college of cardiology clinical expert consensus document on standards for acquisition, measurement and reporting of intravascular ultrasound studies (IVUS). A report of the American college of cardiology task force on clinical expert consensus documents. J Am Coll Cardiol 37(5):1478-1492

8. Pasterkamp G, Schoneveld AH, van der Wal AC, Haudenschild CC, Clarijs RJ, Becker AE, Hillen B, Borst C (1998) Relation of arterial geometry to luminal narrowing and histologic markers for plaque vulnerability: the remodeling paradox. J Am Coll Cardiol 32(3):655-662

9. Varnava AM, Mills PG, Davies MJ (2002) Relationship between coronary artery remodeling and plaque vulnerability. Circulation 105(8):939-943

10. Burke AP, Kolodgie FD, Farb A, Weber D, Virmani R (2002) Morphological predictors of arterial remodeling in coronary atherosclerosis. Circulation 105(3):297-303

11. Kotani J, Mintz GS, Castagna MT, Pinnow E, Berzingi CO, Bui AB, Pichard AD, Satler LF, Suddath WO, Waksman R, Laird JR Jr, Kent KM, Weissman NJ (2003)
Intravascular ultrasound analysis of infarct-related and non-infarct-related arteries in patients who presented with an acute myocardial infarction. Circulation 107(23): 2889-2893

12. Maehara A, Mintz GS, Bui AB, Walter OR, Castagna MT, Canos D, Pichard AD, Satler LF, Waksman R, Suddath WO, Laird JR Jr, Kent KM, Weissman NJ (2002) Morphologic and angiographic features of coronary plaque rupture detected by intravascular ultrasound. J Am Coll Cardiol 40(5):904-910

13. von Birgelen C, Klinkhart W, Mintz GS, Papatheodorou A, Herrmann J, Baumgart D, Haude M, Wieneke H, Ge J, Erbel R (2001) Plaque distribution and vascular remodeling of ruptured and non ruptured coronary plaques in the same vessel: an intravascular ultrasound study in vivo. J Am Coll Cardiol 37(7):1864-1870

14. Jeremias A, Spies C, Herity NA, Pomerantsev E, Yock PG, Fitzgerald PJ, Yeung AC (2000) Coronary artery compliance and adaptive vessel remodelling in patients with stable and unstable coronary artery disease. Heart 84(3): 314-319

15. Nakamura M, Nishikawa H, Mukai S, Setsuda M, Nakajima K, Tamada H, Suzuki H, Ohnishi T, Kakuta Y, Nakano T, Yeung AC (2001) Impact of coronary artery remodeling on clinical presentation of coronary artery disease: an intravascular ultrasound study. J Am Coll Cardiol 37(1):63-69

16. Gyongyosi M, Yang P, Hassan A, Domanovits H, Laggner A, Weidinger F, Glogar D (2000) Intravascular ultrasound predictors of major adverse cardiac events in patients with unstable angina. Clin Cardiol 23(7):507-515

17. Gyongyosi M, Yang P, Hassan A, Weidinger F, Domanovits H, Laggner A, Glogar D (1999) Arterial remodelling of native human coronary arteries in patients with unstable angina pectoris: a prospective intravascular ultrasound study. Heart 82(1):68-74

18. Tauth J, Pinnow E, Sullebarger JT, Basta L, Gursoy S, Lindsay J Jr, Matar F (1997) Predictors of coronary arterial remodeling patterns in patients with myocardial ischemia. Am J Cardiol 80(10):1352-1355

19. Rodriguez-Granillo GA, Serruys PW, Garcia-Garcia HM, Aoki J, Valgimigli M, van Mieghem CA, McFadden E, de Jaegere PP, de Feyter P (2006) Coronary artery remodelling is related to plaque composition. Heart 92(3):388-391

20. Virmani R, Burke AP, Farb A, Kolodgie FD (2006) Pathology of the vulnerable plaque. J Am Coll Cardiol 47(8 Suppl):C13-C18

21. Schaar JA, Muller JE, Falk E, Virmani R, Fuster V, Serruys PW, Colombo A, Stefanadis C, Ward Casscells S, Moreno PR, Maseri A, van der Steen AF (2004) Terminology for high-risk and vulnerable coronary artery plaques. Report of a meeting on the vulnerable plaque, June 17 and 18, 2003, Santorini, Greece. Eur Heart J 25(12): 1077-1082

22. Cheruvu PK, Finn AV, Gardner C, Caplan J, Goldstein J, Stone GW, Virmani R, Muller JE (2007) Frequency and distribution of thin-cap fibroatheroma and ruptured plaques in human coronary arteries: a pathologic study. J Am Coll Cardiol 50(10):940-949

23. Cunningham KS, Gotlieb AI (2005) The role of shear stress in the pathogenesis of atherosclerosis. Lab Invest 85(1):9-23 
24. Garcia-Garcia HM, Goedhart D, Schuurbiers JC, Kukreja N, Tanimoto S, Daemen J, Morel MA, Bressers M, van Es GA, Wentzel J, Gijsen F, van der Steen AF, Serruys PW (2006) Virtual histology and remodeling index allow in vivo identification of allegedly high risk coronary plaques in patients with acute coronary syndromes: a three vessel intravascular ultrasound radiofrequency data analysis. Eurointervention 2:338-344

25. Hong MK, Mintz GS, Lee CW, Lee JW, Park JH, Park DW, Lee SW, Kim YH, Cheong SS, Kim JJ, Park SW, Park SJ (2008) A three-vessel virtual histology intravascular ultrasound analysis of frequency and distribution of thin-cap fibroatheromas in patients with acute coronary syndrome or stable angina pectoris. Am J Cardiol 101(5): 568-572

26. Stone GW, Maehara A, Lansky AJ, de Bruyne B, Cristea E, Mintz GS, Mehran R, McPherson J, Farhat N, Marso SP, Parise H, Templin B, White R, Zhang Z, Serruys PW, PROSPECT Investigators (2011) A prospective naturalhistory study of coronary atherosclerosis. N Engl J Med 364(3):226-235

27. Fujii K, Mintz GS, Carlier SG, Costa JR Jr, Kimura M, Sano K, Tanaka K, Costa RA, Lui J, Stone GW, Moses JW, Leon MB (2006) Intravascular ultrasound profile analysis of ruptured coronary plaques. Am J Cardiol 98(4):429-435

28. Kolodgie FD, Gold HK, Burke AP, Fowler DR, Kruth HS, Weber DK, Farb A, Guerrero LJ, Hayase M, Kutys R, Narula J, Finn AV, Virmani R (2003) Intraplaque hemorrhage and progression of coronary atheroma. N Engl J Med 349(24):2316-2325

29. Kruk M, Pregowski J, Mintz GS, Maehara A, Tyczynski P, Witkowski A, Kalinczuk L, Hong YJ, Pichard AD, Satler LF, Kent KM, Suddath WO, Waksman R, Weissman NJ (2007) Intravascular ultrasonic study of gender differences in ruptured coronary plaque morphology and its associated clinical presentation. Am J Cardiol 100(2):185-189

30. Burke AP, Kolodgie FD, Farb A, Weber DK, Malcom GT, Smialek J, Virmani R (2001) Healed plaque ruptures and sudden coronary death: evidence that subclinical rupture has a role in plaque progression. Circulation 103(7): 934-940

31. Jensen LO, Mintz GS, Carlier SG, Fujii K, Moussa I, Dangas G, Mehran R, Stone GW, Leon MB, Moses JW (2006) Intravascular ultrasound assessment of fibrous cap remnants after coronary plaque rupture. Am Heart $\mathbf{J}$ 152(2):327-332

32. Ge J, Chirillo F, Schwedtmann J, Gorge G, Haude M, Baumgart D, Shah V, von Birgelen C, Sack S, Boudoulas H, Erbel R (1999) Screening of ruptured plaques in patients with coronary artery disease by intravascular ultrasound. Heart 81(6):621-627

33. von Birgelen C, Klinkhart W, Mintz GS, Wieneke H, Baumgart D, Haude M, Bartel T, Sack S, Ge J, Erbel R (2000) Size of emptied plaque cavity following spontaneous rupture is related to coronary dimensions, not to the degree of lumen narrowing. A study with intravascular ultrasound in vivo. Heart 84(5):483-488

34. Fujii K, Kobayashi Y, Mintz GS, Takebayashi H, Dangas G, Moussa I, Mehran R, Lansky AJ, Kreps E, Collins M, Colombo A, Stone GW, Leon MB, Moses JW (2003) Intravascular ultrasound assessment of ulcerated ruptured plaques: a comparison of culprit and non culprit lesions of patients with acute coronary syndromes and lesions in patients without acute coronary syndromes. Circulation 108(20):2473-2478

35. Fujii K, Carlier SG, Mintz GS, Takebayashi H, Yasuda T, Costa RA, Moussa I, Dangas G, Mehran R, Lansky AJ, Kreps EM, Collins M, Stone GW, Moses JW, Leon MB (2005) Intravascular ultrasound study of patterns of calcium in ruptured coronary plaques. Am J Cardiol 96(3):352-357

36. Rioufol G, Finet G, Ginon I, Andre-Fouet X, Rossi R, Vialle E, Desjoyaux E, Convert G, Huret JF, Tabib A (2002) Multiple atherosclerotic plaque rupture in acute coronary syndrome: a three-vessel intravascular ultrasound study. Circulation 106(7):804-808

37. Tanaka A, Shimada K, Sano T, Namba M, Sakamoto T, Nishida Y, Kawarabayashi T, Fukuda D, Yoshikawa J (2005) Multiple plaque rupture and C-reactive protein in acute myocardial infarction. J Am Coll Cardiol 45(10): 1594-1599

38. Hong MK, Mintz GS, Lee CW, Kim YH, Lee SW, Song JM, Han KH, Kang DH, Song JK, Kim JJ, Park SW, Park SJ (2004) Comparison of coronary plaque rupture between stable angina and acute myocardial infarction: a threevessel intravascular ultrasound study in 235 patients. Circulation 110(8):928-933

39. Hong MK, Mintz GS, Lee CW, Lee BK, Yang TH, Kim YH, Song JM, Han KH, Kang DH, Cheong SS, Song JK, Kim JJ, Park SW, Park SJ (2005) The site of plaque rupture in native coronary arteries: a three-vessel intravascular ultrasound analysis. J Am Coll Cardiol 46(2):261-265

40. Pregowski J, Tyczynski P, Mintz GS, Kim SW, Witkowski A, Satler L, Kruk M, Waksman R, Maehara A, Weissman NJ (2006) Intravascular ultrasound assessment of the spatial distribution of ruptured coronary plaques in the left anterior descending coronary artery. Am Heart J 151(4): 898-901

41. Tyczynski P, Pregowski J, Mintz GS, Witkowski A, Kim SW, Waksman R, Satler L, Pichard A, Kalinczuk L, Maehara A, Weissman NJ (2005) Intravascular ultrasound assessment of ruptured atherosclerotic plaques in left main coronary arteries. Am J Cardiol 96(6):794-798

42. Rodriguez-Granillo GA, Garcia-Garcia HM, Wentzel J, Valgimigli M, Tsuchida K, van der Giessen W, de Jaegere P, Regar E, de Feyter PJ, Serruys PW (2006) Plaque composition and its relationship with acknowledged shear stress patterns in coronary arteries. J Am Coll Cardiol 47(4):884-885

43. Pregowski J, Tyczynski P, Mintz GS, Kim SW, Witkowski A, Waksman R, Pichard A, Satler L, Kent K, Kruk M, Bieganski S, Ohlmann P, Weissman NJ (2005) Incidence and clinical correlates of ruptured plaques in saphenous vein grafts: an intravascular ultrasound study. J Am Coll Cardiol 45(12):1974-1979

44. Pregowski J, Tyczynski P, Mintz GS, Kim SW, Witkowski A, Waksman R, Pichard A, Satler L, Kent K, Kalinczuk L, Bieganski S, Ohlmann P, Maehara A, Weissman NJ (2006) Comparison of ruptured plaques in native coronary arteries and in saphenous vein grafts: an intravascular ultrasound study. Am J Cardiol 97(5):593-597

45. Rioufol G, Gilard M, Finet G, Ginon I, Boschat J, AndreFouet X (2004) Evolution of spontaneous atherosclerotic 
plaque rupture with medical therapy: long-term follow-up with intravascular ultrasound. Circulation 110(18):28752880

46. Hong MK, Mintz GS, Lee CW, Suh IW, Hwang ES, Jeong YH, Park DW, Kim YH, Han KH, Cheong SS, Kim JJ, Park SW, Park SJ (2007) Serial intravascular ultrasound evidence of both plaque stabilization and lesion progression in patients with ruptured coronary plaques: effects of statin therapy on ruptured coronary plaque. Atherosclerosis 191(1):107-114

47. Rodriguez-Granillo GA, Garcia-Garcia HM, Valgimigli M, Vaina S, van Mieghem C, van Geuns RJ, van der Ent M, Regar E, de Jaegere P, van der Giessen W, de Feyter P, Serruys PW (2006) Global characterization of coronary plaque rupture phenotype using three-vessel intravascular ultrasound radiofrequency data analysis. Eur Heart J

48. Burke AP, Joner M, Virmani R (2006) IVUS-VH: a predictor of plaque morphology? Eur Heart J 27(16): 1889-1890

49. Schartl M, Bocksch W, Koschyk DH, Voelker W, Karsch KR, Kreuzer J, Hausmann D, Beckmann S, Gross M (2001) Use of intravascular ultrasound to compare effects of different strategies of lipid-lowering therapy on plaque volume and composition in patients with coronary artery disease. Circulation 104(4):387-392

50. Okazaki S, Yokoyama T, Miyauchi K, Shimada K, Kurata T, Sato H, Daida H (2004) Early statin treatment in patients with acute coronary syndrome: demonstration of the beneficial effect on atherosclerotic lesions by serial volumetric intravascular ultrasound analysis during half a year after coronary event: the ESTABLISH Study. Circulation 110(9): 1061-1068

51. Nissen SE, Tuzcu EM, Schoenhagen P, Brown BG, Ganz P, Vogel RA, Crowe T, Howard G, Cooper CJ, Brodie B, Grines CL, DeMaria AN (2004) Effect of intensive compared with moderate lipid-lowering therapy on progression of coronary atherosclerosis: a randomized controlled trial. JAMA 291(9):1071-1080

52. Jensen LO, Thayssen P, Pedersen KE, Stender S, Haghfelt $\mathrm{T}$ (2004) Regression of coronary atherosclerosis by simvastatin: a serial intravascular ultrasound study. Circulation 110(3):265-270

53. Petronio AS, Amoroso G, Limbruno U, Papini B, De Carlo M, Micheli A, Ciabatti N, Mariani M (2005) Simvastatin does not inhibit intimal hyperplasia and restenosis but promotes plaque regression in normocholesterolemic patients undergoing coronary stenting: a randomized study with intravascular ultrasound. Am Heart J 149(3):520-526

54. Nishioka H, Shimada K, Kataoka T, Hirose M, Asawa K, Hasegawa T, Yamashita H, Ehara S, Kamimori K, Sakamoto T, Kobayashi Y, Yoshimura T, Yoshiyama M, Takeuchi K, Yoshikawa J (2004) Impact of HMG-CoA reductase inhibitors for non-treated coronary segments. Osaka City Med J 50(2):61-68

55. Tani S, Watanabe I, Anazawa T, Kawamata H, Tachibana E, Furukawa K, Sato Y, Nagao K, Kanmatsuse K, Kushiro $\mathrm{T}$ (2005) Effect of pravastatin on malondialdehyde-modified low-density lipoprotein levels and coronary plaque regression as determined by three-dimensional intravascular ultrasound. Am J Cardiol 96(8):1089-1094
56. Nissen SE, Nicholls SJ, Sipahi I, Libby P, Raichlen JS, Ballantyne CM, Davignon J, Erbel R, Fruchart JC, Tardif J-C, Schoenhagen P, Crowe T, Cain V, Wolski K, Goormastic M, Tuzcu EM (2006) For the ASTEROID Investigators. Effect of very high-intensity statin therapy on regression of coronary atherosclerosis: the ASTEROID trial. JAMA 295(13):1556-1565

57. Takashima H, Ozaki Y, Yasukawa T, Waseda K, Asai K, Wakita Y, Kuroda Y, Kosaka T, Kuhara Y, Ito T (2007) Impact of lipid-lowering therapy with pitavastatin, a new HMG-CoA reductase inhibitor, on regression of coronary atherosclerotic plaque. Circ J 71(11):1678-1684

58. Takayama T, Hiro T, Yamagishi M, Daida H, Hirayama A, Saito S, Yamaguchi T, Matsuzaki M (2009) Effect of rosuvastatin on coronary atheroma in stable coronary artery disease: multicenter coronary atherosclerosis study measuring effects of rosuvastatin using intravascular ultrasound in Japanese subjects (COSMOS). Circ J 73(11):2110-2117

59. Hiro T, Kimura T, Morimoto T, Miyauchi K, Nakagawa Y, Yamagishi M, Ozaki Y, Kimura K, Saito S, Yamaguchi T, Daida H, Matsuzaki M (2009) Effect of intensive statin therapy on regression of coronary atherosclerosis in patients with acute coronary syndrome: a multicenter randomized trial evaluated by volumetric intravascular ultrasound using pitavastatin versus atorvastatin (JAPANACS [Japan assessment of pitavastatin and atorvastatin in acute coronary syndrome] study). J Am Coll Cardiol 54(4): 293-302

60. Tardif JC, Gregoire J, L'Allier PL, Anderson TJ, Bertrand O, Reeves F, Title LM, Alfonso F, Schampaert E, Hassan A, McLain R, Pressler ML, Ibrahim R, Lesperance J, Blue J, Heinonen T, Rodes-Cabau J (2004) Effects of the acyl coenzyme A: cholesterol acyltransferase inhibitor avasimibe on human atherosclerotic lesions. Circulation 110(21): 3372-3377

61. Nissen SE, Tuzcu EM, Brewer HB, Sipahi I, Nicholls SJ, Ganz P, Schoenhagen P, Waters DD, Pepine CJ, Crowe TD, Davidson MH, Deanfield JE, Wisniewski LM, Hanyok JJ, Kassalow LM (2006) Effect of ACAT inhibition on the progression of coronary atherosclerosis. N Engl J Med 354(12):1253-1263

62. Nissen SE, Tsunoda T, Tuzcu EM, Schoenhagen P, Cooper CJ, Yasin M, Eaton GM, Lauer MA, Sheldon WS, Grines CL, Halpern S, Crowe T, Blankenship JC, Kerensky R (2003) Effect of recombinant ApoA-I Milano on coronary atherosclerosis in patients with acute coronary syndromes: a randomized controlled trial. JAMA 290(17):2292-2300

63. Tardif JC, Gregoire J, L'Allier PL, Ibrahim R, Lesperance J, Heinonen TM, Kouz S, Berry C, Basser R, Lavoie MA, Guertin MC, Rodes-Cabau J (2007) Effects of reconstituted high-density lipoprotein infusions on coronary atherosclerosis: a randomized controlled trial. JAMA 297(15):1675-1682

64. Tardif JC, Gregoire J, L'Allier PL, Ibrahim R, Anderson TJ, Reeves F, Title LM, Schampaert E, LeMay M, Lesperance J, Scott R, Guertin MC, Brennan ML, Hazen SL, Bertrand OF (2008) Effects of the antioxidant succinobucol (AGI-1067) on human atherosclerosis in a randomized clinical trial. Atherosclerosis 197(1):480-486 
65. Nissen SE, Tuzcu EM, Libby P, Thompson PD, Ghali M, Garza D, Berman L, Shi H, Buebendorf E, Topol EJ (2004) Effect of antihypertensive agents on cardiovascular events in patients with coronary disease and normal blood pressure: the CAMELOT study: a randomized controlled trial. JAMA 292(18):2217-2225

66. Nissen SE, Tardif JC, Nicholls SJ, Revkin JH, Shear CL, Duggan WT, Ruzyllo W, Bachinsky WB, Lasala GP, Tuzcu EM (2007) Effect of torcetrapib on the progression of coronary atherosclerosis. N Engl J Med 356(13): 1304-1316

67. Rodriguez-Granillo GA, Vos J, Bruining N, Garcia-Garcia HM, de Winter S, Ligthart JM, Deckers JW, Bertrand M, Simoons ML, Ferrari R, Fox KM, Remme W, De Feyter PJ (2007) Long-term effect of perindopril on coronary atherosclerosis progression (from the perindopril's prospective effect on coronary atherosclerosis by angiography and intravascular ultrasound evaluation [PERSPECTIVE] study). Am J Cardiol 100(2):159-163

68. Nissen SE, Nicholls SJ, Wolski K, Nesto R, Kupfer S, Perez A, Jure H, De Larochelliere R, Staniloae CS, Mavromatis K, Saw J, Hu B, Lincoff AM, Tuzcu EM (2008) Comparison of pioglitazone vs glimepiride on progression of coronary atherosclerosis in patients with type 2 diabetes: the PERISCOPE randomized controlled trial. JAMA 299(13):1561-1573

69. Nissen SE, Nicholls SJ, Wolski K, Rodes-Cabau J, Cannon CP, Deanfield JE, Despres JP, Kastelein JJ, Steinhubl SR, Kapadia S, Yasin M, Ruzyllo W, Gaudin C, Job B, Hu B, Bhatt DL, Lincoff AM, Tuzcu EM (2008) Effect of rimonabant on progression of atherosclerosis in patients with abdominal obesity and coronary artery disease: the STRADIVARIUS randomized controlled trial. JAMA 299(13):1547-1560

70. Luscher TF, Pieper M, Tendera M, Vrolix M, Rutsch W, van den Branden F, Gil R, Bischoff KO, Haude M, Fischer D, Meinertz T, Munzel T (2009) A randomized placebocontrolled study on the effect of nifedipine on coronary endothelial function and plaque formation in patients with coronary artery disease: the ENCORE II study. Eur Heart J 30(13):1590-1597

71. Gerstein HC, Ratner RE, Cannon CP, Serruys PW, GarciaGarcia HM, van Es GA, Kolatkar NS, Kravitz BG, Miller DM, Huang C, Fitzgerald PJ, Nesto RW. Effect of rosiglitazone on progression of coronary atherosclerosis in patients with type 2 diabetes mellitus and coronary artery disease. The assessment on the prevention of progression by rosiglitazone on atherosclerosis in diabetes patients with cardiovascular history trial. Circulation

72. Yokoyama M, Komiyama N, Courtney BK, Nakayama T, Namikawa S, Kuriyama N, Koizumi T, Nameki M, Fitzgerald PJ, Komuro I (2005) Plasma low-density lipoprotein reduction and structural effects on coronary atherosclerotic plaques by atorvastatin as clinically assessed with intravascular ultrasound radio-frequency signal analysis: a randomized prospective study. Am Heart J 150(2):287

73. Kawasaki M, Sano K, Okubo M, Yokoyama H, Ito Y, Murata I, Tsuchiya K, Minatoguchi S, Zhou X, Fujita H, Fujiwara H (2005) Volumetric quantitative analysis of tissue characteristics of coronary plaques after statin therapy using three-dimensional integrated backscatter intravascular ultrasound. J Am Coll Cardiol 45(12):1946-1953

74. Serruys PW, Garcia-Garcia HM, Buszman P, Erne P, Verheye S, Aschermann M, Duckers H, Bleie O, Dudek D, Botker HE, von Birgelen C, D'Amico D, Hutchinson T, Zambanini A, Mastik F, van Es GA, van der Steen AF, Vince DG, Ganz P, Hamm CW, Wijns W, Zalewski A (2008) Effects of the direct lipoprotein-associated phospholipase $\mathrm{A}(2)$ inhibitor darapladib on human coronary atherosclerotic plaque. Circulation 118(11):1172-1182

75. Nasu K, Tsuchikane E, Katoh O, Tanaka N, Kimura M, Ehara M, Kinoshita Y, Matsubara T, Matsuo H, Asakura K, Asakura Y, Terashima M, Takayama T, Honye J, Hirayama A, Saito S, Suzuki T (2009) Effect of fluvastatin on progression of coronary atherosclerotic plaque evaluated by virtual histology intravascular ultrasound. JACC Cardiovasc Interv 2(7):689-696

76. Hong MK, Park DW, Lee CW, Lee SW, Kim YH, Kang DH, Song JK, Kim JJ, Park SW, Park SJ (2009) Effects of statin treatments on coronary plaques assessed by volumetric virtual histology intravascular ultrasound analysis. JACC Cardiovasc Interv 2(7):679-688

77. Toi T, Taguchi I, Yoneda S, Kageyama M, Kikuchi A, Tokura M, Kanaya T, Abe S, Matsuda R, Kaneko N (2009) Early effect of lipid-lowering therapy with pitavastatin on regression of coronary atherosclerotic plaque. Comparison with atorvastatin. Circ J 73(8):1466-1472

78. Miyagi M, Ishii H, Murakami R, Isobe S, Hayashi M, Amano $\mathrm{T}$, Arai $\mathrm{K}$, Ohashi $\mathrm{T}$, Uetani $\mathrm{T}$, Matsubara $\mathrm{T}$, Murohara T (2009) Impact of long-term statin treatment on coronary plaque composition at angiographically severe lesions: a nonrandomized study of the history of long-term statin treatment before coronary angioplasty. Clin Ther 31(1):64-73 